conclusion that, although in favourable conditions fish shoals in their waters may be spotted from the air, this method of loeating fish is much too costly and uncertain to be of any practical value to the national fisheries.

\section{The Future of Indian Agriculture}

IN a survey and a forecast of the next twenty years in India (Journal of the Royal Central Asian Society, vol. 19, July 1932), Lieut.-Col. Sir Arnold Wilson makes a strong plea for the introduction of scientific method into public affairs. $\mathrm{He}$ predicts that in twenty years time the population of Asia will have increased by at least 20 per cent, and that in India alone the numbers may have grown to 427 millions. These figures mean that the great problem of the future will be that of food supply. Over the whole of Asia the predominant occupation is agriculture, while in India at least the cultivable area increases very slowly and seems to have reached the limit except for the redemption of barren areas by irrigation. Figures tend to show that in India the food yield has not kept pace with the growth of population, but that the gap has been partly filled by a decrease in the export of grain. Sir Arnold Wilson foresees the dwindling of this export trade and the growth of an import trade in wheat. To balance this, India will have to develop an export of other primary products, but the tendency will be to utilise these at home. An import of fertilisers will, however, be essential, for on the extended use of these in agriculture lies one of the few hopes for the avoidance of famine in the future and the maintenance of the present standard of living, low as it is.

\section{Fenland Exploration in East Anglia}

A communication from Mr. Miles C. Burkitt, which appears in Man for November, announces the inauguration of a committee for the exploration of the fens of East Anglia in connexion with the Cambridge Antiquarian Society and the Prehistoric Society of East Anglia. Recent archæological work in the area, notably a study of the prehistoric waterways by Major Fowler of Ely and of an early metal age site below peat by $\mathrm{Mr}$. Grahame Clark, has served to demonstrate the importance of a region which can afford an unbroken sequence of deposits from quaternary to recent times. It is evident, however, that archæological investigation does not cover a sufficiently wide field for the complete study of the area, but needs supplementing by such studies, for example, as palæobotany and geology. It has, therefore, been decided, as already stated, to appoint a committee of experts to undertake systematic study in the various branches of scientific investigation between which co-operation is essential to a scheme of exploration. The Master of Downing, Prof. A. C. Seward, has consented to act as president and Major Fowler as vice-president of the Committee. Mr. Grahame Clark, Peterhouse, Cambridge, to whom communications relating to the work of the committee should be addressed, will act as secretary.

No. 3291, Vor. 130]

\section{Rediscovery of an 'Extinct' Bird}

RE-APPEARANCES of creatures regarded as extinet are occasionally reported but seldom proved. There can be no reasonable doubt, however, in the case of the black-capped petrel or 'diablotin' of Dominica, Pterodroma hositata. For many years this bird has been regarded as extinct, the last recorded capture having been made in 1871 , but recently reports have become current that odd examples have been seen. The present position is summed up in a short article in the Journal of the Society for the Preservation of the Fauna of the Empire (Sept. 1932, p. 17). In 1900 Richmond stated that he had seen three, more have been observed in Haiti, and on May 2, 1932, Mary Rose (of Roseau, Dominica) invited a naturalist to examine a strange bird found lying helpless at her door after a stormy night. The naturalists who saw it (it died on May 26) agree that it was a 'diablotin' ; and apparently the bird, although extremely rare, still breeds in the mountain fastnesses of Dominica. It is gratifying to find that steps were at once taken to ensure so far as possible the safety of the remnant, and on July 1 a special legislative order was issued granting the petrel full protection.

\section{Magnetic Declination in the United States}

THE U.S. Coast and Geodetic Survey makes magnetic observations at a set of repeat stations every five years, and publishes the results at similar intervals, in the form of tables of secular variation, and of charts showing the results of the original complete survey, made mainly between 1900 and 1910 , brought up to date. A recent pamphlet by D. L. Hazard ("Magnetic Declination in the United States, 1930", U.S. Dept. of Commerce, Coast and Geodetic Survey, Washington; Serial 540, 1932 ; pp. 40, 10 cents) does this for the magnetic declination; the chart gives isogonic lines at $1^{\circ}$ intervals, and lines of equal annual change at $I^{\prime}$ intervals. It contains much tabular matter and information of value to land surveyors, and is issued at a very low price.

\section{Meldola Medal}

THE Meldola medal (the gift of the Society of Maccabrans) is awarded annually to the chemist whose published chemical work shows the most promise and is brought to the notice of the adminis. trators during the year ending December 31 prior to the award. The recipient must be a British subject not more than thirty years of age at the time of the completion of the work. The medal may not be awarded more than once to the same person. In awarding the medal for 1932, the adjudicators will, unless exceptional circumstances arise, give special consideration to work in physical or inorganic chemistry. The next award will be made in January 1933. The Council of the Institute of Chemistry would therefore be glad to have its gttention directed, before December 31, to work of the character indicated. Communications should be addressed to the Registrar of the Institute, 30 Russell Square, London, W.C.I. 